\title{
Phytoplankton growth and microzooplankton grazing along a sub-Arctic fjord (Godthåbsfjord, west Greenland)
}

\author{
Albert Calbet ${ }^{1, *}$, Karen Riisgaard ${ }^{2}$, Enric Saiz ${ }^{1}$, Sara Zamora $^{1}$, Colin Stedmon ${ }^{3,5}$, \\ Torkel Gissel Nielsen ${ }^{2,4}$
}

${ }^{1}$ Institut de Ciències del Mar (CSIC), Passeig Marítim de la Barceloneta 37-49, 08003 Barcelona, Spain

${ }^{2}$ National Institute of Aquatic Resources, DTU Aqua, Section for Ocean Ecology and Climate, Technical University of Denmark, Kavalergården 6, 2920 Charlottenlund, Denmark

${ }^{3}$ National Environmental Research Institute, Department of Marine Ecology, Aarhus University, Frederiksborgvej 399, 4000 Roskilde, Denmark

${ }^{4}$ Greenland Climate Research Center, Greenland Institute of Natural Resources, Kivioq 2, PO Box 570, 3900 Nuuk, Greenland

${ }^{5}$ Present address: National Institute of Aquatic Resources, DTU Aqua, Section for Ocean Ecology and Climate, Technical University of Denmark, Kavalergården 6, 2920 Charlottenlund, Denmark

\begin{abstract}
We evaluated the role of microzooplankton (sensu latto, grazers $<500 \mu \mathrm{m}$ ) in determining the fate of phytoplankton production (PP) along a glacier-to-open sea transect in the Greenland subarctic fjord, Godthåbfjord. Based on the distribution of size fractionated chlorophyll a (chl a) concentrations we established 4 zones: (1) Fyllas Bank, characterized by deep chl a maxima (ca. 30 to $40 \mathrm{~m}$ ) consisting of large cells, (2) the mouth and main branch of the fjord, where phytoplankton was relatively homogeneously distributed in the upper $30 \mathrm{~m}$ layer, (3) inner waters influenced by glacial melt water and upwelling, with high chl a concentrations (up to $12 \mathrm{\mu g} \mathrm{l}^{-1}$ ) in the $>10 \mu \mathrm{m}$ fraction within a narrow (2 m) subsurface layer, and (4) the Kapisigdlit branch of the fjord, ice-free, and characterized with a thick and deep chl a maximum layer. Overall, microzooplankton grazing impact on primary production was variable and seldom significant in the Fyllas Bank and mouth of the fjord, quite intensive (up to $>100 \%$ potential PP consumed daily) in the middle part of the main and Kapisigdlit branches of the fjord, and rather low and unable to control the fast growing phytoplankton population inhabiting the nutrient rich waters in the upwelling area in the vicinity of the glacier. Most of the grazing impact was on the $<10 \mu \mathrm{m}$ phytoplankton fraction, and the major grazers of the system seem to be $>20 \mu \mathrm{m}$ microzooplankton, as deducted from additional dilution experiments removing this size fraction. Overall, little or no export of phytoplankton out of the fjord to the Fyllas Bank can be determined from our data.
\end{abstract}

KEY WORDS: West Greenland coast - Sub-Arctic fjord - Plankton community structure · Microzooplankton · Grazing

Resale or republication not permitted without written consent of the publisher

\section{INTRODUCTION}

The fragility of high latitude ecosystems, their dependence on ice-cover and extreme seasonality in irradiance and temperature make them a major focus of the studies on global change (e.g. Cavalieri et al. 2003, Johannessen et al. 2004, Smetacek \& Nicol 2005). In this regard, west Greenland waters are par- ticularly relevant, not only because they fit into the category of endangered ecosystems but for the potential socioeconomical implications of any change in the pelagic food web. The west Greenland marine ecosystem is very productive and sustains commercial and recreational fishing and hunting, which largely contribute to Greenland's total export income. A disruption in the lower levels of the food web, 
induced for example by climate change, will likely propagate to higher levels in the food chain and threaten the sustainable harvesting of marine resources. For instance, large calanoid copepods are the preferred food source of cod and other commercial fish larvae in west Greenland waters (Bainbridge \& McKay 1968). The copepods feed on microzooplankton and phytoplankton (Barthel 1988, Levinsen et al. 2000a, Saiz \& Calbet 2011) and are vulnerable to changes in their biomass and distributions. In most marine systems, microzooplankton are the major grazers of phytoplankton and very important secondary producers (Levinsen et al. 2000b, Sherr \& Sherr 2002, Calbet \& Landry 2004, Landry \& Calbet 2004). Consequently, the early life and recruitment of many commercially exploited fish stocks ultimately depends on primary production and on how it is channeled to higher trophic levels by microzooplankton and copepods (Levinsen et al. 2000b). It is therefore essential to understand the structure and functioning of the planktonic food web so that potential abrupt changes, which can have considerable economic and ecological impact, can be modeled and possibly predicted as the Greenland climate changes and anthropogenic activities in the region increase.

The Godthåbsfjord area is of great importance for the local fisheries (Storr-Paulsen et al. 2004) and is among the largest fjord systems in the world. Surprisingly, it is understudied, and the majority of research carried out on the plankton ecology of the system has focused on copepods and fish larvae (Munk et al. 2003, Pedersen et al. 2005, Simonsen et al. 2006, Tang et al. 2011). To our knowledge, there are a limited number of studies detailing the microbial food web in these waters and none of them quantify rates of microzooplankton grazing and growth, instead largely inferring microzooplankton grazing from community biomass and equations from the literature (Poulsen \& Reuss 2002, Pedersen et al. 2005, Arendt et al. 2010). This study stands to rectify this and present novel insight into the plankton dynamics and flow of energy through the microzooplankton of this important system.

Here, we focus on the interaction between phytoplankton and microzooplankton with the goal of determining how much of the primary production (PP) is consumed by the microzooplankton (Sherr \& Sherr 2002, Levinsen \& Nielsen 2002, Calbet \& Landry 2004, Calbet 2008). We define the group microzooplankton as all the grazers $<500 \mu \mathrm{m}$, which in our study was mostly protozoans. The area investigated encompasses 2 important spawning areas for the Greenland cod Gadus morhua: the Fyllas Bank and
Godthåbsfjord (Storr-Paulsen et al. 2004). Along the fjord we expected to traverse very contrasting trophic scenarios. Offshore, Fyllas Bank is highly influenced by the oceanography of the west Greenland Shelf and Davis Strait. The entrance and main body of Godthåbsfjord experience extensive tidal mixing and water exchange (Mortensen et al. 2011), leading to enhanced production of phytoplankton (Arendt et al. 2010). The inner part of the Godthåbsfjord is influenced by glacial nutrient-rich melt water and characterized by high phytoplankton abundances (Mortensen et al. 2011, Tang et al. 2011). Finally, the Kapisigdlit branch of the fjord is mostly unaffected by direct glacial melt water and is a known area of spawning for cod (Storr-Paulsen et al. 2004).

\section{MATERIALS AND METHODS}

This study was part of the Biological Oceanography of Fyllas Bank-Godthåbsfjord (BOFYGO) cruise that was conducted with RV 'Dana' from June 6 to 24, 2010. The sampling area spanned the Fyllas Bank, off southwestern Greenland, to the inner part of the Godthåbsfjord (Table 1, Fig. 1). At each station salinity, temperature, and chlorophyll a fluorescence profiles were recorded during the early morning using a CTD (SBE 19plus, SeaCat) and a Turner Designs fluorometer (Cyclops 7). Water samples for the determination of inorganic nutrients and chlorophyll a concentrations (hereafter $\mathrm{chl} \mathrm{a)} \mathrm{were} \mathrm{obtained} \mathrm{using} \mathrm{a}$ rosette with twelve 101 Niskin bottles. Dissolved inorganic nutrient samples (phosphate, nitrate, and silicate) were immediately frozen $\left(-20^{\circ} \mathrm{C}\right)$ for later analysis on a Skalar autoanalyser (Breda, Netherlands), following the procedures of Hansen \& Koroleff (1999). The precision (analytical reproducibility) of the nutrient analyses was $0.06,0.1$, and $0.2 \mu \mathrm{M}$ for phosphate, nitrate, and silicate, respectively.

We also estimated the phytoplankton growth and the microzooplankton grazing rates using the dilution technique (Landry \& Hassett 1982) at each station on total (GF/F filtered) and $>10 \mu \mathrm{m} \mathrm{chl} \mathrm{a.} \mathrm{The}$ water for the experiments was collected at the fluorescence maximum (Table 1) using 301 Niskin bottles. We gravity-filtered a portion of the water through a Pall Acropak 0.8/0.2 500 capsule $(0.2 \mu \mathrm{m}$ final pore size) that, together with its tubing, was flushed previously with diluted $\mathrm{HCl}$ and rinsed thoroughly afterwards with deionized water. We then poured measured volumes into a series of 2.31 acidwashed polycarbonate bottles for each dilution treatment. At stations in which the fluorescence profile 
showed very high values at the maximum, we sampled and filtered water from just below the fluorescence maximum to avoid filter clogging. The remaining volume of the bottles was filled to the top with $500 \mu \mathrm{m}$ nylon-mesh reverse-filtered natural seawater from the selected depth to produce the following dilution series: $12.5,25,50,75$, and $100 \%$ of natural water. Visual examination after the filling of the bottles revealed no significant numbers of copepods in them. Moreover, an examination of 21 of the initial water filtered through $40 \mu \mathrm{m}$ mesh did not show many copepods either (maximum 1 to 2 small Oithona spp.). All handling and filtration was carried out under dim light conditions to avoid cell light-damage. To fulfill the assumptions of the method, instantaneous phytoplankton growth should be the same in all the dilution bottles. To ensure this, each bottle was amended with $10 \mu \mathrm{M}$ of ammonium $\left(\mathrm{NH}_{4} \mathrm{Cl}\right), 0.7 \mu \mathrm{M}$ of phosphate $\left(\mathrm{Na}_{2} \mathrm{HPO}_{4}\right)$, and 1 to $2 \mu \mathrm{M}$ of silicate $\left(\mathrm{Na}_{2} \mathrm{SiO}_{3}\right)$. The added nitrogen was in the form of ammonium because it is more readily taken up by algae than nitrate (Dortch et al. 1991). We also added silicate to promote constant growth of diatoms. In addition, 2 extra $100 \%$ (i.e. undiluted) bottles were prepared without nutrients to assess the natural growth of the algae and to serve as initial samples. Each 2.31 bottle was used to sequentially fill (gentle

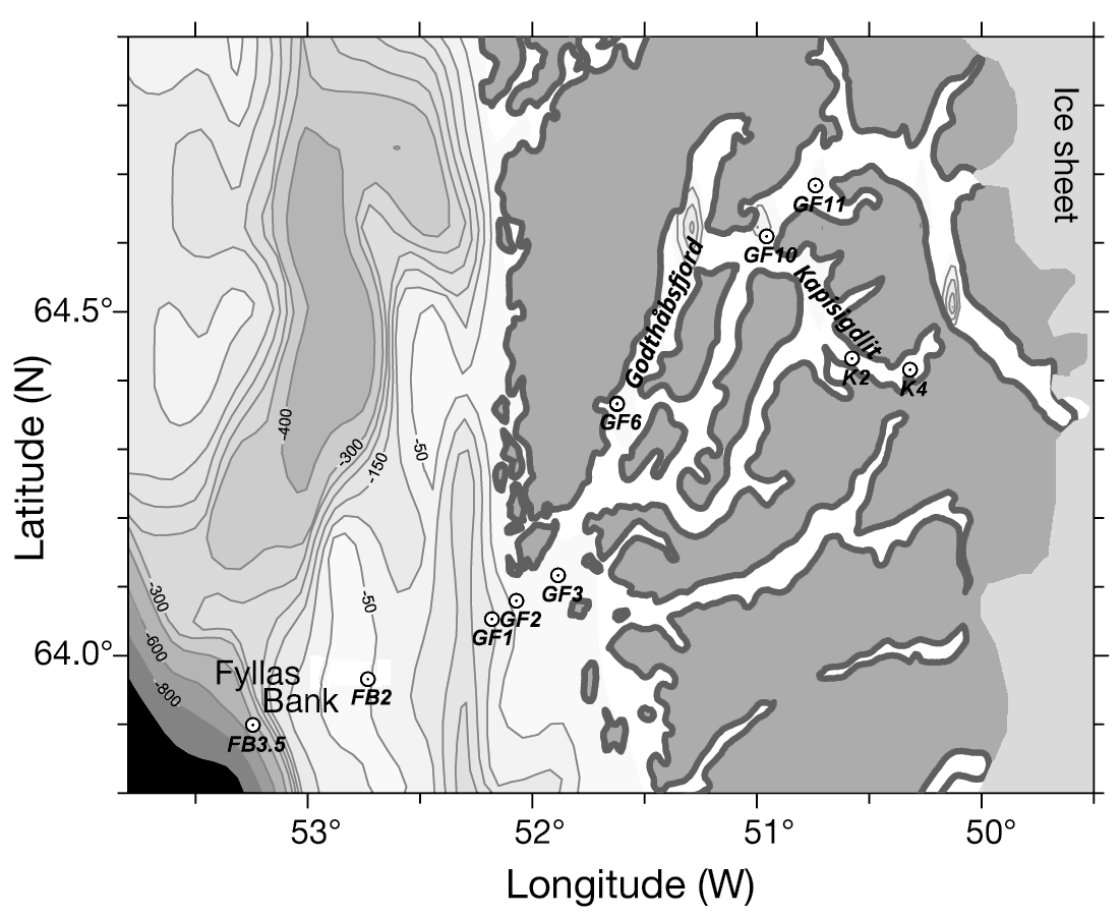

Fig. 1. Study area in and near Godthåbsfjord, west Greenland indicating the locations of the sampled stations (๑). FB: Fyllas Bank; GF: Godthåbsfjord; K: Kapisigdlit branch

siphoning) 2 replicated dilution incubation bottles (1 1 acid-washed polycarbonate).

At Stns GF6, GF11 and K2 we carried out an additional dilution grazing experiment in which we reverse filtered the natural water through a $20 \mu \mathrm{m}$ sieve. Otherwise, these bottles were treated as above. The aim of this experiment was to investigate whether grazing of phytoplankton was due to small zooplankton $(<20 \mu \mathrm{m})$ or large ones $(20$ to $500 \mu \mathrm{m})$. By removing the $>20 \mu \mathrm{m}$ fraction, the food chain is

Table 1. Locations of the sampling stations and chlorophyll a concentrations of samples collected at each station during June 2010. Stations were located along a transect beginning offshore at Fyllas Bank, heading inland and ending in the inner fjord. Water depth indicates depth at which sample was collected. Incubation temperature, initial concentration of chlorophyll $a$ (Total $=$ GFF filtered duplicated samples), and proportion of $>10 \mu \mathrm{m}$ chl a relate to the experimental conditions and results. $\mathrm{SE}$ of $2 \mathrm{chl}$ a replicated samples

\begin{tabular}{|c|c|c|c|c|c|c|c|c|}
\hline Area & Stn & $\begin{array}{l}\text { Day of } \\
\text { month }\end{array}$ & $\begin{array}{l}\text { Latitude } \\
\text { (N) }\end{array}$ & $\begin{array}{l}\text { Longitude } \\
\text { (W) }\end{array}$ & $\begin{array}{l}\text { Incubation } \\
\text { temp. }\left({ }^{\circ} \mathrm{C}\right)\end{array}$ & $\begin{array}{l}\text { Water depth } \\
(\mathrm{m})\end{array}$ & $\begin{array}{c}\text { Total chl a } \\
\left( \pm \mathrm{SE}, \mu \mathrm{g} \mathrm{l}^{-1}\right)\end{array}$ & $\begin{array}{l}\% \mathrm{chl} a \\
>10 \mu \mathrm{m}\end{array}$ \\
\hline Fyllas Bank & FB3.5 & 8 & $63^{\circ} 53.9^{\prime}$ & $53^{\circ} 14.7^{\prime}$ & 4.9 & 20 & $1.46 \pm 0.096$ & 64.8 \\
\hline Fyllas Bank & FB2 & 10 & $63^{\circ} 58.0^{\prime}$ & $52^{\circ} 44.0^{\prime}$ & 5.2 & 30 & $1.24 \pm 0.012$ & 91.3 \\
\hline Outer fjord & GF1 & 12 & $64^{\circ} 03.2^{\prime}$ & $52^{\circ} 10.9^{\prime}$ & 3.6 & 10 & $2.21 \pm 0.038$ & 10.6 \\
\hline Outer fjord & GF2 & 13 & $64^{\circ} 04.8^{\prime}$ & $52^{\circ} 04.2^{\prime}$ & 3.7 & 30 & $0.70 \pm 0.006$ & 22.6 \\
\hline Outer fjord & GF3 & 11 & $64^{\circ} 07.0^{\prime}$ & $51^{\circ} 53.0^{\prime}$ & 3.6 & 25 & $1.07 \pm 0.012$ & 26.2 \\
\hline Inner fjord & GF6 & 15 & $64^{\circ} 22.0^{\prime}$ & $51^{\circ} 37.4^{\prime}$ & 4.3 & 25 & $2.70 \pm 0.046$ & 16.6 \\
\hline Near glacier & GF10 & 16 & $64^{\circ} 36.6^{\prime}$ & $50^{\circ} 57.5^{\prime}$ & 5.6 & 12 & $4.87 \pm 0.166$ & 92.7 \\
\hline Near glacier & GF10bis & 21 & $64^{\circ} 36.6^{\prime}$ & $50^{\circ} 57.5^{\prime}$ & 6.6 & 15 & $7.23 \pm 0.019$ & 83.5 \\
\hline Near glacier & GF11 & 20 & $64^{\circ} 41.0^{\prime}$ & $50^{\circ} 44.4^{\prime}$ & 2.6 & 18 & $12.2 \pm 0.238$ & 86.9 \\
\hline Kapisigdlit & K2 & 17 & $64^{\circ} 25.1^{\prime}$ & $50^{\circ} 34.5^{\prime}$ & 8.0 & 20 & $1.33 \pm 0.043$ & 42.1 \\
\hline Kapisigdlit & K4 & 18 & $64^{\circ} 24.6^{\prime}$ & $50^{\circ} 19.1^{\prime}$ & 7.3 & 25 & $1.10 \pm 0.013$ & 20.4 \\
\hline
\end{tabular}


disrupted and grazers $<20 \mu \mathrm{m}$ are favoured, as their predators are absent. Therefore, if $<20 \mu \mathrm{m}$ grazers were responsible for most of the grazing activity on phytoplankton, these fractionated experiments should show either equal or higher grazing coefficients than the standard dilution experiments conducted with the same water. Conversely, if major grazers were $>20 \mu \mathrm{m}$, the grazing detected in these bottles should be severely diminished.

We incubated all the bottles in a 6001 opaque PVC incubator with open-circuit water running from a $5 \mathrm{~m}$ depth at a temperature about the same as that in situ. To guarantee similar light intensities to that at the fluorescence maximum we dimmed the natural sunlight with an appropriate dark plastic mesh (reduction of 80 to $90 \%$ of surface light, depending on the station). The bottles were gently mixed by repeated turning and repositioned in the incubator at least 4 times per day. The incubations were terminated after 25 to $30 \mathrm{~h}$, and samples for the quantification of total and $>10 \mu \mathrm{m}$ chl a concentrations were taken. For $<20 \mu \mathrm{m}$ treatments, only the total chl a was measured.

To determine total chl $a$, we filtered 100 to $200 \mathrm{ml}$ of water (depending on the dilution level) under low vacuum pressure $(<100 \mathrm{~mm} \mathrm{Hg})$ through Whatmann glass fibre filters (GF/F, $25 \mathrm{~mm}$ diameter). For the $>10 \mu \mathrm{m}$ fraction, we filtered 150 to $300 \mathrm{ml}$ through $10 \mu \mathrm{m}$ polycarbonate filters $(25 \mathrm{~mm}$ diameter, Osmonics). After filtration, the filters were stored frozen at $-20^{\circ} \mathrm{C}$ until analysis and then extracted in $96 \%$ ethanol at room temperature for 12 to $18 \mathrm{~h}$ (Jespersen \& Christoffersen 1987). Fluorescence was then measured before and after acidification, on a fluorometer (TD-700, Turner Designs) calibrated with a pure chl a standard. The fluorescence signal measured by the fluorometer deployed with the CTD was calibrated with extracted chl a measurements from the entire vertical profile using a linear regression. A separate regression was carried out for each station as the relationship was found to vary across the transect. The calibrated fluorescence profiles are used here to only reveal the relative vertical distribution of the phytoplankton biomass and its links to water column structure. For calculations, only the laboratory measured chl a concentrations are used.

Acid Lugol preserved samples (1\% final concentration) were taken to characterize the initial microplankton concentration. Unfortunately, the commercial Lugol used was inappropriate to preserve microzooplankton, and samples were lost, except for Stns GF10bis, GF11, K2, and K4 that were preserved with self-made Lugol (Throndsen 1978). Although these samples do not provide a comprehensive view of the microplankton distribution along the fjord, they are presented to have a better understanding of these sites. The samples were processed by settling $100 \mathrm{ml}$ in Utermöhl chambers for at least $48 \mathrm{~h}$ prior to counting them using an inverted microscope (XSB1A). The whole chamber, or a fraction of it for the smallest and more abundant organisms, was counted at 100,250 , and $400 \times$ magnification, depending on the group. Fifty to 100 cells per group were sized, adjusted to their closest geometric shape, and converted into carbon using the equations of MendenDeuer \& Lessard (2000).

Phytoplankton mortality rates $\left(m ; \mathrm{d}^{-1}\right)$ were computed as the slope of the linear regression between net growth rate of chl $a$ and the dilution factor for the nutrient-amended bottles (Landry \& Hassett 1982). Instantaneous phytoplankton growth rates $\left(\mu_{;} \mathrm{d}^{-1}\right)$ in the dilution grazing experiments were obtained by adding the net growth in the unamended bottles $\left(K_{\mathrm{o} i} \mathrm{~d}^{-1}\right.$; no nutrients added) to the mortality rate of microzooplankton from dilution experiments when the latter was significant $\left(\mu=K_{\mathrm{o}}+m\right)$. Potential primary

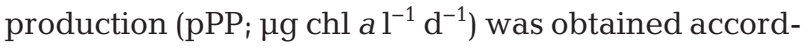
ing to Landry et al. (2000) by multiplying $\mu$ by the average concentration of chl a during the incubation $\left(C_{\mathrm{m} i} C_{\mathrm{m}}=C_{\mathrm{o}}\left[\mathrm{e}^{(\mu-m) t}-1\right] /(\mu-m) t\right)$, where $C_{\mathrm{o}}$ is the initial chl a concentration and $t$ is the incubation time (d).

\section{RESULTS}

\section{Physical environment}

Different oceanographic regimes were observed along the transect (Figs. 1 \& 2). At the Fyllas Bank stations (Stns FB3.5 and FB2) the upper $100 \mathrm{~m}$ of the water column consisted largely of 2 layers: a warm $\left(>3^{\circ} \mathrm{C}\right)$ surface layer between 10 and $15 \mathrm{~m}$ thick with a salinity of approximately 33.1 and an underlying layer of colder $\left(<2^{\circ} \mathrm{C}\right)$ and slightly more saline water (Fig. 2). At the region near the entrance of the fjord between the Bank and the eastern most fjord sill (Stns GF1-GF3) the water column was comparatively well mixed (Fig. 2). Further east into the main branch of the fjord and towards both the glaciers and Kapisigdlit, the water column was stratified (Stn GF6). The warmest waters were measured at the surface of the Kapisigdlit branch (Stns K2 and K4), whilst the lowest salinity surface waters were found where glacier melt water was influential (GF 10 and 11).

The regional differences in the water column structure were also mirrored in the vertical distribution of 
Salinity
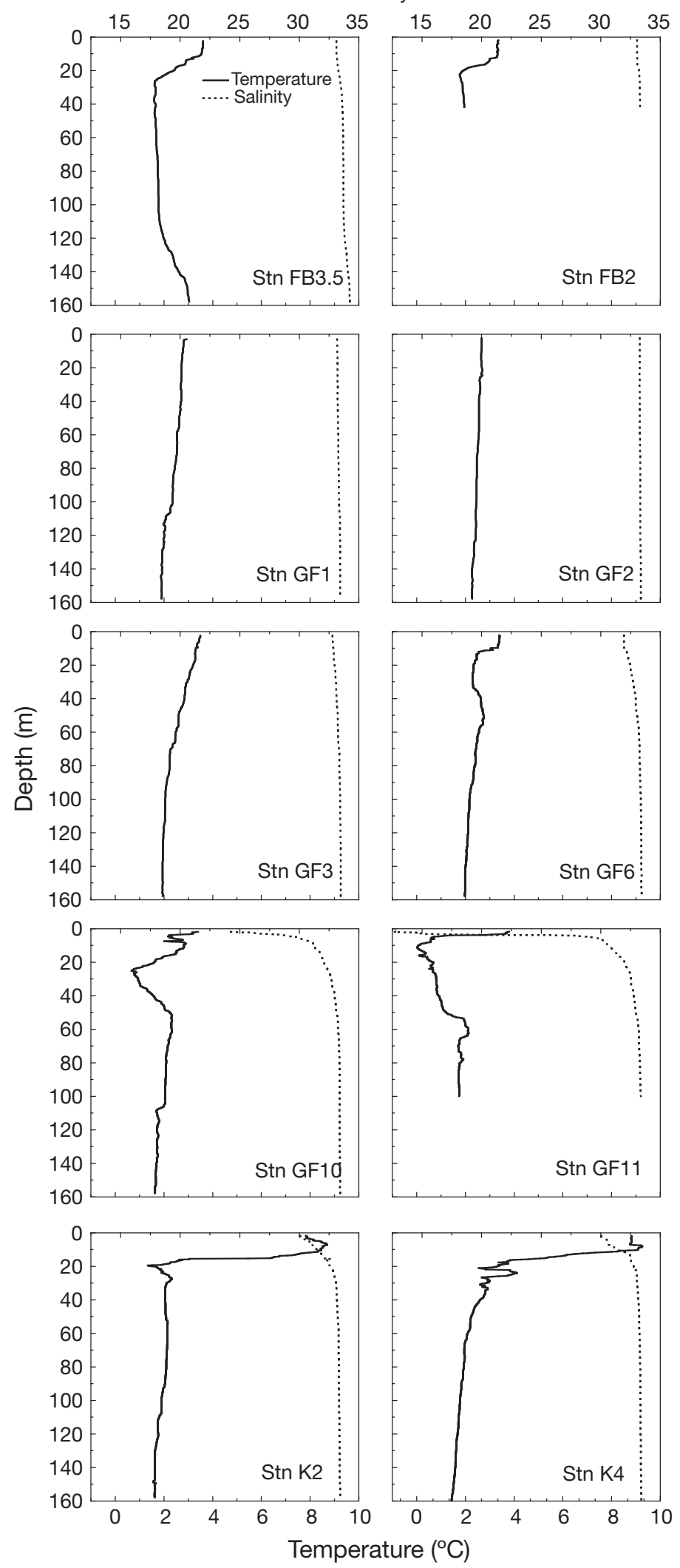

Fig. 2. Profiles of temperature and salinity at the sampled stations. See Fig. 1 for station abbreviations and locations
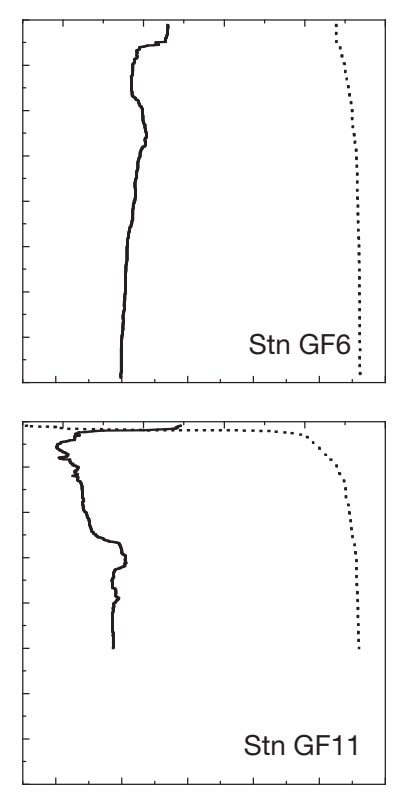
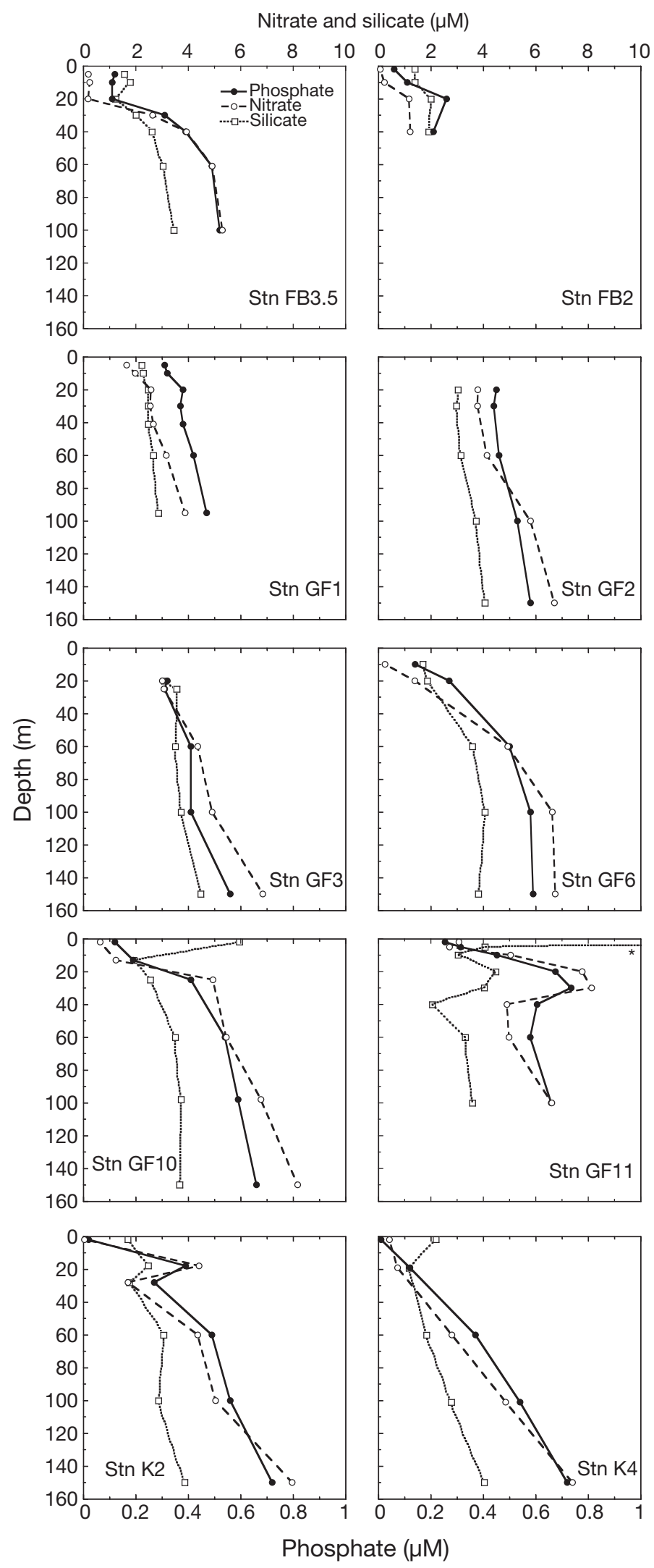

Fig. 3. Profiles of inorganic nutrient concentrations at the sampled stations. See Fig. 1 for station abbreviations and locations. ${ }^{*}$ Silicate maximum concentration $23.7 \mu \mathrm{M}$ 
the major nutrients (Fig. 3). At the Fyllas Bank nutrients were depleted in the upper mixed part of the water column (Fig. 3). In the outer mixed part of the fjord (Stns GF1-GF3) high concentrations of all major nutrients were measured throughout the water column. In the Kapisigdlit branch (Stns K2 and K4) the phosphate and nitrate were close to detection limit in the upper freshwater-impacted part of the water column, from where they increased towards the bottom (Fig. 3). The highest surface concentrations of nutrients were measured at the innermost station in the Godthåbsfjord, where the freshwater outlet from the glacier resulted in subglacial circulation (Mortensen et al. 2011) that caused upwelling of nutrient rich subsurface water (Stn GF11).

\section{Community structure}

The initial concentrations of chl $a$ at the fluorescence maximum for each experiment and the proportion of the total chl $a>10 \mu \mathrm{m}$ are presented in Table 1. Total chl a concentrations at the fluores- cence maximum were quite similar at most stations, ranging from 0.7 to $2.7 \mu \mathrm{g} \mathrm{chl} \mathrm{a} \mathrm{l}^{-1}$. However, concentrations were greater near the glacier (4.87 to

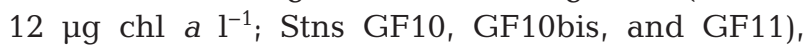
which mostly corresponded to $>10 \mu \mathrm{m}$ cells (diatom chains; Table 2). Small cells dominated the phytoplankton community biomass at the mouth of the main fjord and in the Kapisigdlit branch. At the latter stations (Stns K2 and K4), a very heterotrophic community was present with a clear predominance of large ciliates (Table 2).

The vertical distribution of $\mathrm{chl} a$ is presented in Fig. 4. Fyllas Bank stations showed a deep chl a maximum ca. 30 to $40 \mathrm{~m}$ (note Stn FB2 was a very shallow station on the Bank). At the mouth and sill region of Godthåbsfjord (Stn GF2), phytoplankton were relatively homogeneously distributed. In the fjord and beyond the sill region a clear subsurface chl a maximum was again found in a narrow and distinct layer matching the thermal stratification (Figs. $3 \& 4$ ). On the other hand, in the Kapisigdlit stations the chl a maximum was very wide and reached very deep layers, quite below the thermocline (Fig. 4).

Table 2. Mean $\left( \pm \mathrm{SE}\right.$ ) biomass $\left(\mu \mathrm{g} \mathrm{C}^{-1}\right.$ ) of protists at the stations near the glacier (GF10bis and GF11) and Kapisigdlit fjord (K2 and K4) from 2 initial bottle measurements (see 'Materials and methods' section). Biomass of dominant taxa for each station is shown in bold

\begin{tabular}{|c|c|c|c|c|c|c|c|c|}
\hline & \multicolumn{2}{|c|}{ GF10bis } & \multicolumn{2}{|c|}{ GF11 } & \multicolumn{2}{|c|}{ K2 } & \multicolumn{2}{|c|}{ K4 } \\
\hline & Mean & SE & Mean & SE & Mean & $\mathrm{SE}$ & Mean & $\mathrm{SE}$ \\
\hline \multicolumn{9}{|l|}{ Diatoms } \\
\hline Chaetoceros spp. & 27.9 & 0.25 & 10.9 & 0.6 & 12.1 & 0.32 & 1.1 & 0.04 \\
\hline Pseudo-nitzschia spp. & 0.03 & 0.004 & 0.01 & 0.001 & 0.01 & 0.002 & 0.004 & 0.001 \\
\hline Thalassiosira spp. & 54.3 & 3.16 & 147.0 & 4.1 & 2.2 & 0.51 & 0.18 & 0.06 \\
\hline Other centric diatoms & 7.6 & 0.79 & 5.4 & 0.15 & 2.8 & 0.14 & 0.40 & 0.05 \\
\hline Other pennate diatoms & 0.14 & 0.003 & 0.04 & 0.01 & 0.01 & 0.01 & 0.00 & 0.00 \\
\hline \multicolumn{9}{|l|}{ Flagellates } \\
\hline Dinobryon spp. & 0.04 & 0.01 & 0.02 & 0.002 & 0.22 & 0.02 & 0.37 & 0.05 \\
\hline Phaeocystis sp. & 0.99 & 0.31 & 0.00 & 0.00 & 0.25 & 0.01 & 0.31 & 0.05 \\
\hline Other nanoflagellates & 1.0 & 0.05 & 1.35 & 0.33 & 0.57 & 0.02 & 0.59 & 0.004 \\
\hline \multicolumn{9}{|l|}{ Dinoflagellates } \\
\hline Amphidinium sphenoides & 0.59 & 0.06 & 0.64 & 0.03 & 0.16 & 0.01 & 0.21 & 0.00 \\
\hline Dinophysis spp. & 0.05 & 0.05 & 0.00 & 0.00 & 0.90 & 0.75 & 2.0 & 0.05 \\
\hline Gyrodinium spp. & 6.3 & 0.69 & 7.61 & 0.82 & 10.6 & 0.47 & 12.2 & 2.6 \\
\hline Katodinium glaucum & 0.05 & 0.01 & 0.03 & 0.003 & 0.03 & 0.01 & 0.06 & 0.02 \\
\hline Protoperidinium spp. & 0.24 & 0.09 & 0.24 & 0.02 & 0.79 & 0.00 & 1.17 & 0.11 \\
\hline Torodinium robustum & 0.15 & 0.06 & 0.02 & 0.00 & 0.83 & 0.08 & 0.19 & 0.02 \\
\hline Other dinoflagellates $(<20 \mu \mathrm{m})$ & 0.59 & 0.02 & 0.53 & 0.06 & 2.4 & 0.06 & 0.96 & 0.07 \\
\hline Other dinoflagellates $(>20 \mu \mathrm{m})$ & 4.2 & 0.32 & 3.93 & 0.15 & 8.5 & 1.8 & 9.0 & 1.5 \\
\hline \multicolumn{9}{|l|}{ Ciliates } \\
\hline Laboea strobila & 0.00 & 0.00 & 0.00 & 0.00 & 4.3 & 0.98 & 18.3 & 0.30 \\
\hline Strombidium spp. & 0.55 & 0.14 & 0.07 & 0.07 & 10.4 & 0.89 & 4.4 & 0.34 \\
\hline Tintinnida & 0.15 & 0.02 & 0.14 & 0.04 & 0.05 & 0.05 & 0.00 & 0.00 \\
\hline Other ciliates $(<20 \mu \mathrm{m})$ & 0.06 & 0.01 & 0.05 & 0.00 & 0.07 & 0.001 & 2.20 & 0.22 \\
\hline Other ciliates (> $20 \mu \mathrm{m})$ & 23.0 & 3.09 & 17.5 & 0.15 & 50.6 & 7.63 & 265.9 & 21.9 \\
\hline
\end{tabular}




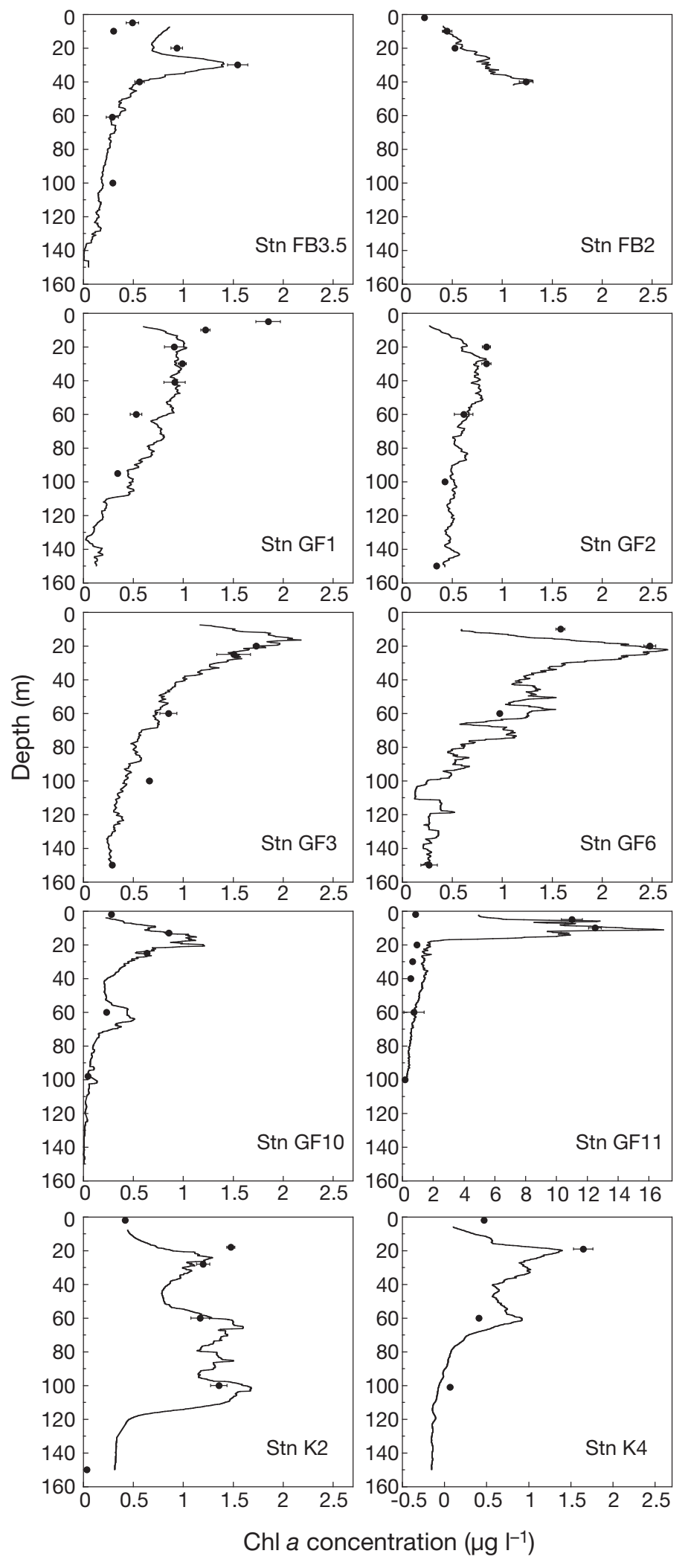

Fig. 4. Vertical distribution of chl $a$ at each of the sampled stations. Continuous line indicates the calibrated fluorescence from the CTD mounted fluorometer. Dots correspond to the actual chl a measurements (mean $\pm \mathrm{SE}, \mathrm{n}=3$ ). Note the different scale at Stn GF11

\section{Phytoplankton growth and mortality rates}

The analysis of the net growth rates in the $100 \%$ bottles without added nutrients $\left(K_{0}\right)$ provide a proxy for the short-term natural evolution of the community during the incubations, although it does not resolve the mechanisms behind the observed rates (phytoplankton mortality versus growth). With this in mind, the data presented in Table 3 provide evidence that for most stations the phytoplankton community was growing or was rather stable (slightly diminishing in Stns FB3.5 and K4 for total chl a). For the main Godthåbsfjord stations, excluding Stn GF3 (see below), net growth rates increased towards the inner fjord and glaciers. Globally, net phytoplankton growth rates $\left(K_{0}\right)$ showed a significant relationship with chl a (Fig. 5). The comparison of the net growth rates in bottles without added nutrients $\left(K_{0}\right)$ with those amended $(K)$ reveals that the areas with lower concentrations of chl a showed important phytoplankton growth enhancement because of the nutrient amendment (Fig. 6). On the other hand, there was no apparent growth enhancement as a result of the addition of nutrients in the areas with higher chl a concentrations (Stns GF10bis and GF11; Fig. 6).

Besides the information provided by the net growth rates, further insights are obtained when these rates are analyzed together with the dilution experiments, as these provide estimates of instantaneous phytoplankton growth and mortality rates. These data show that the phytoplankton community was growing at higher instantaneous rates $(0.2$ to $0.4 \mathrm{~d}^{-1}$ ) at the inner part of the main fjord and at

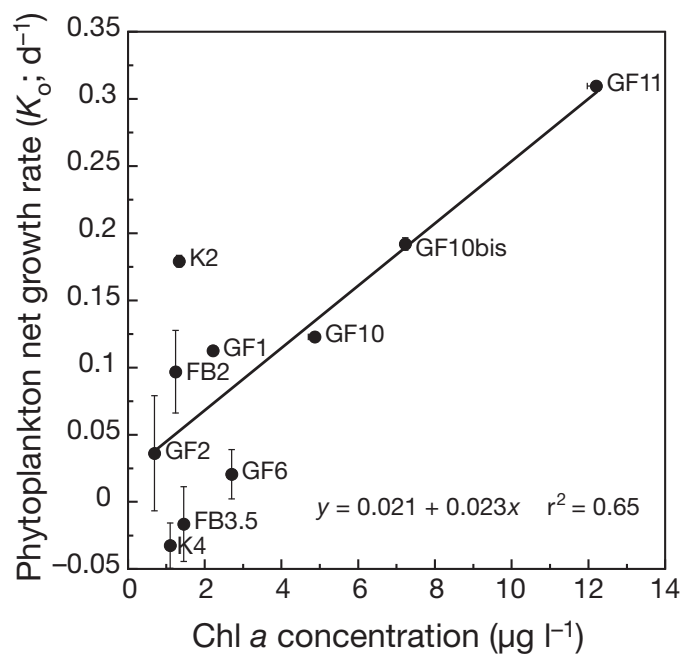

Fig. 5. Relationship between initial chl a concentrations and net growth rates without nutrient addition at the sampled stations. Stn GF3 was excluded from the analysis (see 'Results'). Error bars are SE of 2 replicates 
Table 3. Summary of the dilution grazing experiment results for total chl a (GFF based) and $>10 \mu \mathrm{m}$ chl $a$ at each station. The determination coefficients for the regression analyses are provided for the significant $(\mathrm{p}<0.05)$ regressions. $K_{\mathrm{o}}$ : phytoplankton net growth rate; $\mu$ :instantaneous growth rate in the $100 \%$ bottles without nutrients $\left(\mu=K_{0}+m\right) ; m$ : mortality rate; pPP: potential primary production; \% pPP: percentage of phytoplankton potential production daily removed by grazers $(m / \mu \times 100)$; ns: not significant; nd: not determined because positive slope in the regression

\begin{tabular}{|c|c|c|c|c|c|c|}
\hline Stn & $\begin{array}{c}K_{\mathrm{o}} \\
\left(\mathrm{d}^{-1}\right)\end{array}$ & $\underset{\left(d^{-1}\right)}{\mu}$ & $\underset{\left(d^{-1}\right)}{m}$ & $\mathrm{r}^{2}$ & $\begin{array}{c}\mathrm{pPP} \\
\left(\mu \mathrm{g} \mathrm{chl} a \mathrm{l}^{-1} \mathrm{~d}^{-1}\right)\end{array}$ & $\% \mathrm{pPP}$ \\
\hline \multicolumn{7}{|c|}{ Total chl a } \\
\hline FB3.5 & -0.02 & 0.20 & 0.22 & 0.72 & 0.29 & 110.2 \\
\hline FB2 & 0.10 & 0.10 & ns & ns & 0.14 & 0.0 \\
\hline GF1 & 0.11 & 0.11 & ns & ns & 0.26 & 0.0 \\
\hline GF2 & 0.04 & 0.32 & $0.28^{\mathrm{a}}$ & 0.70 & 0.23 & 87.4 \\
\hline GF3 & -0.29 & -0.29 & nd & 0.89 & & 0.0 \\
\hline GF6 & 0.02 & 0.39 & $0.37^{a}$ & 0.72 & 1.1 & 94.8 \\
\hline GF10 & 0.12 & 0.33 & 0.21 & 0.48 & 1.9 & 64.0 \\
\hline GF10bis & 0.19 & 0.19 & ns & $\mathrm{ns}$ & 1.5 & 0.0 \\
\hline GF11 & 0.31 & 0.39 & $0.07^{\mathrm{b}}$ & 0.48 & 6.0 & 19.9 \\
\hline $\mathrm{K} 2$ & 0.18 & 0.36 & 0.18 & 0.61 & 0.5 & 49.7 \\
\hline K4 & -0.03 & 0.11 & 0.14 & 0.74 & 0.12 & 127.8 \\
\hline \multicolumn{7}{|c|}{$>10 \mu \mathrm{m} \mathrm{chl} a$} \\
\hline FB3.5 & 0.16 & 0.405 & $0.25^{\mathrm{b}}$ & 0.59 & & \\
\hline FB2 & -0.01 & -0.01 & ns & ns & & \\
\hline GF1 & 0.21 & 0.21 & ns & ns & & \\
\hline GF2 & -0.25 & -0.25 & ns & ns & & \\
\hline GF3 & 0.30 & 0.30 & ns & ns & & \\
\hline GF6 & 0.09 & 0.37 & $0.28^{\mathrm{b}}$ & 0.60 & & \\
\hline GF10 & 0.18 & 0.27 & $0.09^{b}$ & 0.59 & & \\
\hline GF10bis & 0.19 & 0.27 & 0.08 & 0.55 & & \\
\hline GF11 & 0.42 & 0.42 & ns & $\mathrm{ns}$ & & \\
\hline $\mathrm{K} 2$ & 0.20 & 0.20 & ns & ns & & \\
\hline $\mathrm{K} 4$ & 0.14 & 0.14 & ns & ns & & \\
\hline
\end{tabular}

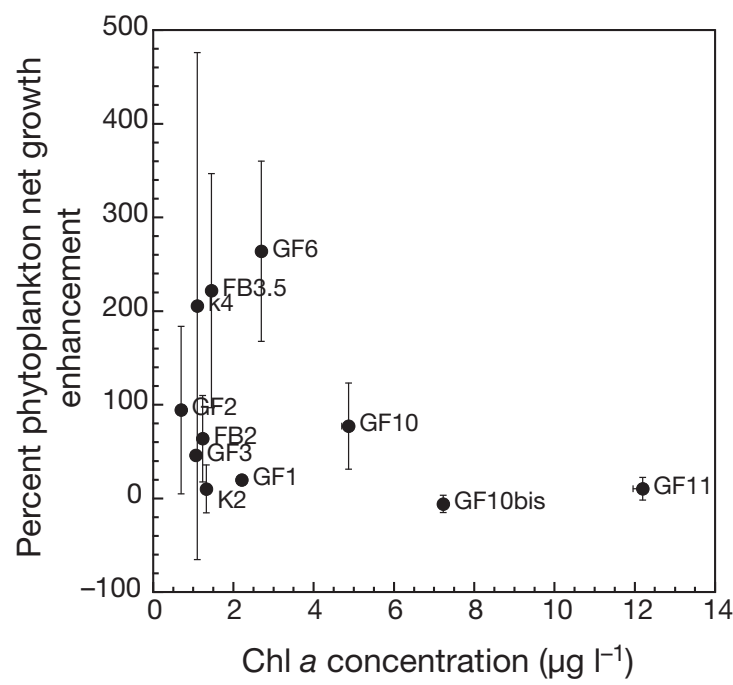

Fig. 6. Net phytoplankton growth rate enhancement due to nutrient addition in the $100 \%$ dilution experiment bottles compared to the unamended bottles at each station: $(K-$ $\left.K_{\mathrm{o}}\right) / K_{\mathrm{o}} \times 100$; see 'Materials and methods'. Error bars along the abscissa axis are the SE of 2 replicates. Error bars along the ordinate axis are SE and have been calculated by applying the corresponding error propagation equations lower rates in the mouth and adjacent Fyllas Bank area $\left(0.1\right.$ to $0.2 \mathrm{~d}^{-1}$; Table 3$)$.

The microzooplankton grazing control on phytoplankton, as a percentage of the potential primary production (pPP) consumed per day (Table 3, Fig. 7), reveals a close coupling between producers and grazers in the middle part of the fjord and Kapisigdlit branch, a globally low, although very variable, grazing pressure in the Fyllas Bank and mouth part of the fjord, and an overall low pressure in the inner part of the Godthåbsfjord near the glacier. For this analysis we excluded Stn GF3 because the positive slope of the relationship between net growth rates and dilution factor, likely a result of trophic cascades during the incubations (Calbet et al. 2011), prevents any interpretation of the data.

To better characterize the microbial food web structure of the system, we analysed the grazing activity on $>10 \mu \mathrm{m}$ phytoplankton in the standard dilution grazing experiments and on total chl $a$ in the experiments without organisms $>20 \mu \mathrm{m}$. These data provide a measure of both the microzooplankton 


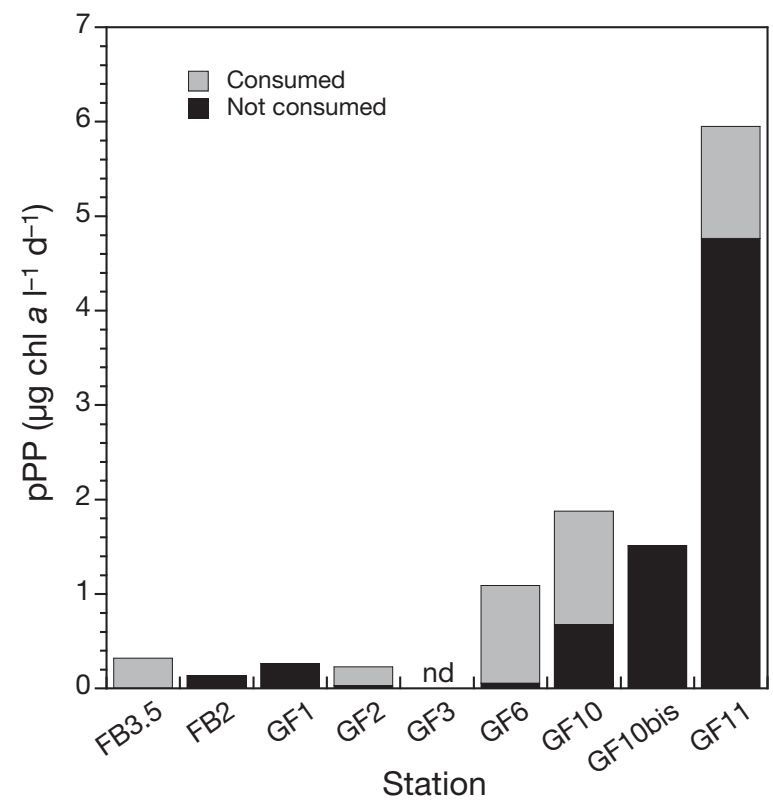

Fig. 7. Potential primary production (pPP) at stations in the main branch of Godthåbfjord (G) and the Fyllas Bank (FB) area. The proportion of the pPP grazed by microzooplankton is indicated. nd: not determined

grazing impact on large phytoplankton and further insights into the size-fractions of the major grazers of the system. The grazing activity on $>10 \mu \mathrm{m}$ cells was only significant at Stns FB3.5, GF6, and 2 visits to Stn GF10 (Table 3). In the experiments where the food web was truncated by removing organisms $>20 \mu \mathrm{m}$ (Stns GF6, GF11 and K2), we observed a clear reduction in grazing rates in 2 out of 3 stations (Table 4), which indicates that $>20 \mu \mathrm{m}$ grazers were exerting an important impact on the phytoplankton of the area.

\section{DISCUSSION}

\section{Main scenario}

In this section we will define how the physiochemical characteristics of the area shape the distribution of phytoplankton and how this is reflected in well defined zones within the study area.

Fyllas Bank stations consisted of a combination of sub-polar mode water and coastal water, the latter representing polar water from the Arctic Ocean that has been modified by mixing during its transit south along the east Greenland coast and around Cape Farewell (Mortensen et al. 2011). In summer, increased ice melt and warming often influence these surface waters (Mortensen et al. 2011). Near the entrance of the fjord the water column was homoge-
Table 4. Mean growth and mortality rates and regression determination coefficient from the $<20 \mu \mathrm{m}$ pre-filtered dilution grazing experiments for two Godthåbsfjord stations (GF6 and GF11) and one Kapisigdlit branch station (K2). $K_{\mathrm{o}}$ : phytoplankton net growth rate without added nutrients; $\mu$ :instantaneous growth rate without nutrients; $m$ : mortality rate; ns: not significant

\begin{tabular}{|lrccc|}
\hline Stn & $\begin{array}{c}K_{\mathrm{o}} \\
\left(\mathrm{d}^{-1}\right)\end{array}$ & $\begin{array}{c}\mu \\
\left(\mathrm{d}^{-1}\right)\end{array}$ & $\begin{array}{c}m \\
\left(\mathrm{~d}^{-1}\right)\end{array}$ & $\mathrm{r}^{2}$ \\
\hline GF6 & 0.03 & 0.03 & $\mathrm{~ns}$ & $\mathrm{~ns}$ \\
GF11 & 0.15 & 0.25 & 0.10 & $\begin{array}{c}0.52 \\
\text { K2 }\end{array}$ \\
\hline
\end{tabular}

neous, due to the constrained bathymetry and extensive tidal mixing. Overall, stratified surface waters were depleted in nutrients, except in areas with substantial vertical mixing, such as the sill and glacier region, where nutrient-rich subsurface waters are upwelled (Mortensen et al. 2011), replenishing nutrient concentrations. From the station furthest inside the fjord moving outward to the ocean, the surface nutrient concentration gradually decreased. This characteristic distribution of inorganic nutrients matches the distribution, community size-structure, and activity of phytoplankton; high concentrations of fast-growing large cells were found near the glacier and small, less-abundant cells in the mouth of the main fjord and the Kapisigdlit branch. Whether this distribution is a characteristic of the area or a particular condition cannot be concluded at the present time as there are no previous studies on the subject in this branch of the fjord. In the open waters of the Fyllas Bank the chl $a$ was mostly found in the $>10 \mu \mathrm{m}$ size fraction. These results support the findings of Arendt et al. (2010) in the same area in May 2006. According to these authors, Thalassiosira spp. represented the bulk of net phytoplankton near the glacier, which was corroborated by our observations, whereas other centric diatoms and prymnesiophyte Phaeocystis spp. largely contributed to the total abundance of phytoplankton in the rest of the fjord and adjacent coastal areas.

The differences observed in water column characteristics, chl a concentration and size composition allow us to establish 4 main areas in the study region: the Fyllas Bank stations, those in the mouth and sill region, the stations near the glacier, and the stations in the Kapisigdlit branch. The main biological areas established in this study based on the distribution, biomass and size structure of the phytoplankton community add further detail to the major domains described in the area according the hydrographic characteristics (Mortensen et al. 2011, Tang et al. 
2011). This biological zonation of the fjord, as well as the distribution of $\mathrm{chl} a_{\text {, coincide with previous }}$ reports from the area (Arendt et al. 2010, Tang et al. 2011) and seem to be driven by the physical and chemical characteristics, mostly resulting from the interaction of the glacier water runoff with the circulatory patterns in the fjord (Mortensen et al. 2011). Nevertheless, some additional biological traits (e.g. grazing) may affect the structure of the community of producers.

\section{Phytoplankton growth and mortality rates}

Phytoplankton instantaneous growth rates (i.e. potential growth in the absence of grazing), even considering the in situ temperatures, are in the lower range of the average phytoplankton growth rates gathered by Calbet \& Landry (2004) for polar (mostly Antarctic) areas. However, they are close to more recent estimates in different areas of the Arctic (Strom et al. 2007, Sherr et al. 2009, Calbet et al. 2011). When grazing is taken into account, the net phytoplankton growth rates in the unamended bottles $\left(K_{0}\right)$ show a significant relationship with chl $a$. Such a relationship seems to indicate a continuous nutrient supply where algae developed in dense blooms (i.e. in the vicinities of the glacier). These blooms appear not to be nutrient limited, as deducted by the null phytoplankton growth enhancement shown for the areas with higher chl a concentrations (Fig. 6). However, away from the direct influence of the glacier the differences between the nutrientamended bottles and the unamended ones became, although variable, very substantial (up to ca. $250 \%$ ). Some of this variability is because small differences in very low rates (some close to zero) sometimes result in a huge proportional increase, which calls for some caution when drawing general conclusions from these data. Nevertheless, our results seem to consistently indicate that in summer the majority of the nutrients supplied by fjord circulation and melt water at the glacier area are taken up and few nutrients are exported out of the fjord. This is also corroborated by the vertical profile of inorganic nutrients (Fig. 3) and coincides with the findings of Arendt et al. (2010).

The question that remains to be answered, however, is whether the grazing by the microzooplankton can control the expansion of the phytoplankton bloom out of the fjord. The percentage of the potential primary production consumed per day indicates microzooplankton (dominated by large athecate dinoflagellates inside the fjord and by $>40 \mu \mathrm{m}$ ciliates in the Fyllas Bank stations; Arendt et al. 2010) are unable to cope with the fast growing and numerous diatom chains forming the major bloom. This indicates the minor influence that microzooplankton had on very large cells (mostly diatom chains) and agrees with findings from other Arctic semi-enclosed areas (Strom et al. 2007). Consequently, most of the autotrophic biomass produced in the vicinity of the glacier likely settled, in the absence of strong mesozooplankton grazing. This seems to be the case, as the estimated copepod grazing impact on the phytoplankton of the fjord is very low (Arendt et al. 2010, Tang et al. 2011). The only available microzooplankton grazing estimates in the area are those from Arendt et al. (2010), which were obtained by converting protozoan biomass into growth using temperature-related equations and then assuming a gross growth efficiency of $33 \%$ (Hansen et al. 1997). These data are likely to be overestimations, given the assumption of an entirely autotrophic ingestion. Nevertheless, their estimate for grazing in fjord waters ( $37 \%$ of the pPP consumed daily) is not far from our estimates $(44 \%$, average for all Godthåbsfjord stations). On the other hand, our limited sampling in the Fyllas Bank rendered quite contrasting results (from 0 to $110 \%$ of the pPP consumed daily) to the earlier study $(20 \%)$, although obviously, given the variability of our results, within the range.

\section{A remark on the methodology used}

An important aspect of our methodology is the addition of not only dissolved inorganic nitrogen and phosphorus to the dilution series, but also dissolved silicate in the form of $\mathrm{Na}_{2} \mathrm{SiO}_{3}$. The dilution technique (Landry \& Hassett 1982) relies on several assumptions. A very important one is that phytoplankton growth rates should be unaffected by the dilution. If nutrients are limiting phytoplankton growth, diluting the sample may result in a higher growth in the more diluted treatments. The common way to circumvent this is to add enough nutrients to guarantee that the growth of the algae is unaffected by dilution. This necessitates the addition of a control series without nutrient addition in order to estimate the actual phytoplankton instantaneous growth rates. However, in the majority of studies using this technique the nutrients added are phosphate, nitrate and sometimes ammonium; silicate is seldom added to the experimental bottles. This omission to the nutrient pool may result in an overestimation of mor- 
tality rates in these systems dominated by diatoms and under dissolved silicate deplete conditions. If one nutrient is limiting, provided that direct uptake is faster and more efficient than the uptake of regenerated nutrients, the most diluted bottles will offer a richer environment for the less abundant cells. This implies that phytoplankton net growth rates in these bottles will be proportionally higher than in the bottles where the concentration of algae is larger and where the nutrients are depleted faster, leading to an increase in the slope of the regression equation between phytoplankton growth and dilution factor. Unfortunately, if this artefact occurs, it is difficult to detect and microzooplankton grazing rates will be overestimated. We therefore recommend the addition of silicate together with ammonium and phosphate to the dilution grazing experiments conducted in areas dominated by diatoms or in those where this nutrient may be limiting.

\section{Conclusions}

Overall, little of the PP generated near the glacier is exported out of the fjord. Whether this is a result of microzooplankton grazing activity in the fjord or sedimentation in the vicinity of the glacier remains to be determined. In any case, the grazing activity of the microzooplankton serves to retain the phytoplankton carbon in the surface layer rather than accelerate the vertical flux, as does grazing by mesozooplankton (Wassmann 1998). In the inner part of the fjord, where melt water from the glacier causes subglacial circulation (Mortensen et al. 2011) and upwelling of nutrient-rich waters in front of the glacier, the growth rate of the phytoplankton is much higher than the grazing capacity of the microzooplankton; however, as the water leaves the fjord the phytoplankton deplete the nutrients and the consumption from microzooplankton balances their production. Therefore, the phytoplankton production along the fjord waters seems to be retained in the system by microzooplankton, allowing little or no direct export production to the Fyllas Bank.

Acknowledgements. This research was funded by the project BOFYGO (from the board of the Danish Centre for Marine Research, DCH) and projects Oithogreen (CTM 2010-10036-E) and PROTOS (CTM2009-08783) (funded by the Ministry of Science and Innovation) assigned to T.G.N., E.S. and A.C., respectively. We thank the Greenland Climate Centre for support and logistics, and we are indebted to the captain and crew of the RV 'Dana' and to the colleagues on board for their invaluable help and support dur- ing the cruise. B. Søborg is thanked for excellent technical assistance. P. Munk provided Fig. 1. Finally, we thank 2 anonymous reviewers for their help and efforts in improving the manuscript.

\section{LITERATURE CITED}

Arendt KE, Nielsen TG, Rysgaard S, Tönnesson K (2010) Differences in plankton community structure along the Godthåbsfjord, from the Greenland Ice Sheet to offshore waters. Mar Ecol Prog Ser 401:49-62

Bainbridge V, McKay BJ (1968) The feeding of cod and redfish larvae. ICNAF Spec Publ 7:187-217

Barthel KG (1988) Feeding of three Calanus species on different phytoplankton assemblages in the Greenland Sea. Meeresforsch Rep Mar Res 32:92-106

Calbet A (2008) The trophic roles of microzooplankton in marine systems. ICES J Mar Sci 65:325-331

Calbet A, Landry MR (2004) Phytoplankton growth, microzooplankton grazing, and carbon cycling in marine systems. Limnol Oceanogr 49:51-57

> Calbet A, Saiz E, Almeda R, Movilla JI, Alcaraz M (2011) Low microzooplankton grazing rates in the Arctic Ocean during a Phaeocystis pouchetii bloom (Summer 2007): fact or artifact of the dilution technique? J Plankton Res 33:687-701

> Cavalieri DJ, Parkinson CL, Vinnikov KY (2003) 30-Year satellite record reveals contrasting Arctic and Antarctic decadal sea ice variability. Geophys Res Lett 30, 1970, doi: 10.1029/2003GL018031

> Dortch Q, Thompson PA, Harrison PJ (1991) Short-term interaction between nitrate and ammonium uptake in Thalassiosira pseudonana: effect of preconditioning nitrogen source and growth rate. Mar Biol 110:183-193

Gallegos CL (1989) Microzooplanton grazing on phytoplankton in the Rhode River, Maryland: nonlinear feeding kinetics. Mar Ecol Prog Ser 57:23-33

Hansen HP, Koroleff F (1999) Determination of nutrients. In: Grasshoff K, Kremling K, Ehrhardt M (eds) Methods of seawater analysis, 3rd edn. Wiley-VCH, Weinheim, p 159-228

> Hansen PJ, Bjørnsen PK, Hansen BW (1997) Zooplankton grazing and growth: scaling within the 2-2,000- $\mu \mathrm{m}$ body size range. Limnol Oceanogr 42:687-704

Jespersen AM, Christoffersen K (1987) Measurements of chlorophyll-a from phytoplankton using ethanol as extraction solvent. Arch Hydrobiol 109:445-454

Johannessen OM, Bengtsson L, Miles MW, Kuzmina SI and others (2004) Arctic climate change: observed and modelled temperature and sea-ice variability. Tellus A 56: 328-341

> Landry MR, Calbet A (2004) Microzooplankton production in the oceans. ICES J Mar Sci 61:501-507

> Landry MR, Hassett RP (1982) Estimating the grazing impact of marine micro-zooplankton. Mar Biol 67: 283-288

> Landry MR, Constantinou J, Latasa M, Brown SL, Bidigare RR, Ondrusek ME (2000) Biological response to iron fertilization in the eastern equatorial Pacific (IronEx II). III. Dynamics of phytoplankton growth and microzooplankton grazing. Mar Ecol Prog Ser 201:57-72

> Levinsen H, Nielsen TG (2002) The trophic role of marine pelagic ciliates and heterotrophic dinoflagellates in arctic and temperate coastal ecosystems: a cross-latitude 
comparison. Limnol Oceanogr 47:427-439

Levinsen H, Nielsen TG, Hansen BW (2000a) Annual succession of marine pelagic protozoans in Disko Bay, West Greenland, with emphasis on winter dynamics. Mar Ecol Prog Ser 206:119-134

Levinsen H, Turner JT, Nielsen TG, Hansen BW (2000b) On the trophic coupling between protists and copepods in arctic marine ecosystems. Mar Ecol Prog Ser 204:65-77

Menden-Deuer S, Lessard EJ (2000) Carbon to volume relationships for dinoflagellates, diatoms, and other protist plankton. Limnol Oceanogr 45:569-579

Mortensen J, Lennert K, Bendtsen J, Rysgaard S (2011) Heat sources for glacial melt in a sub-Arctic fjord (Godthåbsfjord) in contact with the Greenland Ice Sheet. J Geophys Res 116, C01013, doi:10.1029/2010JC006528

Munk P, Hansen BW, Nielsen TG, Thomsen HA (2003) Changes in plankton and fish larvae communities across hydrographic fronts off West Greenland. J Plankton Res 25:815-830

> Pedersen SA, Ribergaard MH, Simonsen CS (2005) Microand mesozooplankton in Southwest Greenland waters in relation to environmental factors. J Mar Syst 56:85-112

Poulsen LK, Reuss N (2002) The plankton community on Sukkertop and Fylla Banks off West Greenland during a spring bloom and post-bloom period: hydrography, phytoplankton and protozooplankton. Ophelia 56:69-85

Saiz E, Calbet A (2011) Copepod feeding in the ocean: scaling patterns, composition of their diet and the bias of estimates due to microzooplankton grazing during incu-

Editorial responsibility: Matthias Seaman,

Oldendorf/Luhe, Germany bations. Hydrobiologia 666:181-196

Sherr EB, Sherr BF (2002) Significance of predation by protists in aquatic microbial food webs. Antonie van Leeuwenhoek 81:293-308

> Sherr EB, Sherr BF, Hartz AJ (2009) Microzooplankton grazing impact in the Western Arctic Ocean. Deep-Sea Res II 56:1264-1273

Simonsen CS, Munk P, Folkvord A, Pedersen SA (2006) Feeding ecology of Greenland halibut and sandeel larvae off West Greenland. Mar Biol 149:937-952

Smetacek V, Nicol S (2005) Polar ocean ecosystems in a changing world. Nature 437:362-368

> Storr-Paulsen M, Wieland K, Hovgård H, Rätz H (2004) Stock structure of Atlantic cod (Gadus morhua) in West Greenland waters: implications of transport and migration. ICES J Mar Sci 61:972-982

Strom SL, Macri EL, Olson MB (2007) Microzooplankton grazing in the coastal Gulf of Alaska: variations in topdown control of phytoplankton. Limnol Oceanogr 52: 1480-1494

Tang KW, Nielsen TG, Munk P, Mortensen J and others (2011) Metazooplankton community structure, feeding rate estimates, and hydrography in a meltwater-influenced Greenlandic fjord. Mar Ecol Prog Ser 434:77-90

Throndsen J (1978). Preservation and storage. In: Sournia A (ed) Phytoplankton manual. UNESCO, Paris, p 69-74

> Wassmann P (1998) Retention versus export food chains: processes controlling sinking loss from marine pelagic systems. Hydrobiologia 363:29-57

Submitted: May 9, 2011; Accepted: August 12, 2011

Proofs received from author(s): November 11, 2011 